\title{
Coumarin analogue 3-methyl-7H-furo[3,2-g] chromen-7-one as a possible antiparkinsonian agent
}

María del Pilar Olaya ${ }^{1}$, Nadezdha Esperanza Vergel ${ }^{1}$, José Luis López ${ }^{2}$, María Dolores Viña ${ }^{3}$, Mario Francisco Guerrero ${ }^{1}$

${ }^{1}$ Departamento de Farmacia, Facultad de Ciencias, Universidad Nacional de Colombia, Bogotá, D.C., Colombia

2 Departamento de Química Farmacéutica, Facultad de Farmacia, Universidad de Salamanca, Salamanca, España

${ }^{3}$ Departamento de Farmacología, Centro de Investigación en Medicina Molecular y Enfermedades Crónicas, Universidad de Santiago de Compostela, Santiago de Compostela, España

Introduction: Parkinson's disease is the second most common neurodegenerative disease. Monoamine oxidase $B$ inhibitors are used in the treatment of this disease concomitantly with levodopa or as monotherapy. Several substituted coumarins have shown activity as inhibitors of monoamine oxidase B.

Objective: To evaluate the possible antiparkinsonian effects of the coumarin analogue FCS005 (3-methyl-7H-furo[3,2-g]chromen-7-one) in mouse models, as well as its inhibitory activity towards monoamine oxidases (MAO) and its antioxidant activity.

Materials and methods: FCS005 was synthesized and the reversal of hypokinesia was evaluated in the reserpine and levodopa models. Moreover, in the haloperidol model, its anticataleptic effects were evaluated. Additionally, the monoamine oxidase inhibitory activity and antioxidant activity of FCS005 were evaluated using in vitro and ex vivo studies, respectively. Results: FCS005 (100 mg/kg) caused the reversal of hypokinesia in the reserpine and levodopa models. This furocoumarin also presented anti-cataleptic effects at the same dose. Besides, it showed selective inhibitory activity towards the MAO-B isoform and antioxidant activity.

Received: $31 / 01 / 18$ Accepted: 29/10/18 Published: 09/11/18

Citation:

Olaya MP, Vergel NE, López JL, Viña MD, Guerrero MF. Coumarin analogue 3-methyl-7H-furo[3,2-g] chromen-7-one as a possible antiparkinsonian agent. Biomédica. 2019;39:491-501.

https://doi.org/10.7705/biomedica.4299

Corresponding author:

María del Pilar Olaya, Departamento de Farmacia, Universidad Nacional de Colombia, Avenida carrera 30 N 45-03, Bogotá, D.C., Colombia

Telephone: (571) 316 5000, extension 14622; fax: (571) 3165060

mpolayao@unal.edu.co

\section{Author contributions:}

María del Pilar Olaya: Development of the in vivo studies of reserpine and levodopa/carbidopa models, participation in the process of synthesis and drafting of the paper

Nadezdha Esperanza Vergel: Development of the in vivo study of the haloperidol model, of the process of synthesis and the antioxidant activity assay José Luis López: Direction of the process of synthesis of coumarin

Dolores Viña: Development of the in vitro inhibition of MAO

Mario Francisco Guerrero: Development of the statistical analysis and the critical revision of the manuscript content

All authors reviewed and approved the final version of this manuscript.

Funding:

This work was funded by the Universidad Nacional de Colombia, Bogotá (VRI/DIB, Project: 13668).

Conflicts of interest:

The authors declare that there are no conflicts of interest.
Conclusion: These results attribute interesting properties to the compound FCS005. It is important to continue research on this molecule considering that it could be a potential antiparkinsonian agent.

Keywords: Parkinson's disease; monoamine oxidase; coumarins; models, animal; reserpine; levodopa; haloperidol; antioxidants.

\section{El análogo de cumarina 3-metil-7H-furo[3,2-g]cromen-7-ona, un posible agente antiparkinsoniano}

Introducción. El segundo trastorno neurodegenerativo más común es la enfermedad de Parkinson. Los inhibidores de la monoamino oxidasa B se emplean en el tratamiento de esta enfermedad en monoterapia o concomitantemente con levodopa. Varios compuestos cumarínicos han mostrado actividad como inhibidores de la monoamino oxidasa B. Objetivo. Evaluar los posibles efectos antiparkinsonianos del análogo de la cumarina FCS005 (3-methyl-7H-furo[3,2-g]chromen-7-one) en modelos de ratones, la actividad inhibitoria frente a las monoamino oxidasas (MAO) y la actividad antioxidante.

Materiales y métodos. Se sintetizó la furanocumarina FCS005 y, en los modelos de reserpina y levodopa, se evaluó si producía reversión de la hipocinesia; en el modelo de haloperidol se evaluaron sus efectos anticatalépticos. Además, se evaluó in vitro la actividad inhibidora de MAO y, ex vivo, la actividad antioxidante del compuesto FCS005. Resultados. El compuesto FCS005 en dosis de $100 \mathrm{mg} / \mathrm{kg}$ produjo la remisión de la hipocinesia en los modelos de reserpina y de levodopa. Esta furanocumarina presentó efectos anticatalépticos con la misma dosis. Además, mostró tener actividad inhibitoria selectiva sobre la MAO B, así como efectos antioxidantes.

Conclusión. Los resultados evidenciaron propiedades interesantes del compuesto FCS005. Es importante continuar investigando esta molécula porque puede ser un potencial agente antiparkinsoniano.

Palabras clave: enfermedad de Parkinson; monoaminooxidasa; cumarinas; modelos animales; reserpina; levodopa; haloperidol; antioxidantes.

Parkinson's disease is the second most common neurodegenerative disease after Alzheimer's. The incidence of the disease ranges from 10 to 50/100,000 person-years with a prevalence between 100 and 300/100,000 population (1). Due to the general aging of the population, the number of 
Parkinson's disease patients is expected to double by $2030(1,2)$. The loss of dopamine-secreting neurons within the substantia nigra and the presence of Lewy bodies are the major pathological findings in Parkinson's disease (3) while resting tremor, bradykinesia, muscle rigidity, and alterations in balance and walking are its main motor symptoms $(4,5)$.

Currently, levodopa (L-dopa) is the most widely used treatment for the disease. This symptomatic therapy compensates for the decreased level of dopamine (DA). In certain instances (e.g., mild symptoms, tremor as the only or most prominent symptom, aged $<60$ years), other medications as monoamine oxidase type B inhibitors may be used initially to avoid levodopa-related motor complications (3). The MAO-B inhibitors such as selegiline and rasagiline are a valuable adjunct therapy to L- DOPA for Parkinson's disease (6). These agents improve the response to L-dopa in the later stages of the disease and are useful in the treatment of disease symptoms in early stages (7).

Several coumarin compounds present activity in the central nervous system (CNS). Coumarin (1,2-benzopyrone) obtained from the species Hygrophila tyttha Leonard has shown potential effects as an anticonvulsant, anxiolytic, and sedative (8). One study indicated that 4-propyl-2H-benzo[h]-chromen2-one could have antidepressant effects (9). Different substituted coumarins have been synthesized and have shown activity as MAO-B inhibitors (10$15)$ and other coumarin derivatives have presented neuroprotective effects $(16,17)$, which is important considering that currently it is expected that therapeutic alternatives control Parkinson's disease symptoms and offer an approach to slow or stop the progression of neurodegeneration (18). Several coumarins have shown antioxidant activity $(19,20)$, which has an interesting neuroprotective property as oxidative stress is among the main risk factors underlying nigral degeneration. Dopaminergic neurons in this region of the CNS are particularly susceptible to oxidative stress (21).

In this study, the coumarin FCS005 (3-methyl-7H-furo[3,2-g]chromen-7-one) was synthesized and its possible anti-parkinsonian effects were evaluated.

\section{Materials and methods}

\section{Coumarin analogue}

FCS005 is a furocoumarin obtained from a 7-hydroxylated coumarin following the experimental protocol previously described by Garazd, et al. (22). It is an amorphous yellow powder with a melting point at $210-212^{\circ} \mathrm{C}$ and a molecular weight of $200 \mathrm{~g} / \mathrm{mol}$. The infrared and ${ }^{1} \mathrm{H} /{ }^{13} \mathrm{C}$ magnetic resonance spectra led to the elucidation of the structure of 3-methyl-7H-furo[3,2-g] chromen-7-one (figure 1) reported in the National Center for Biotechnology Information database (23).

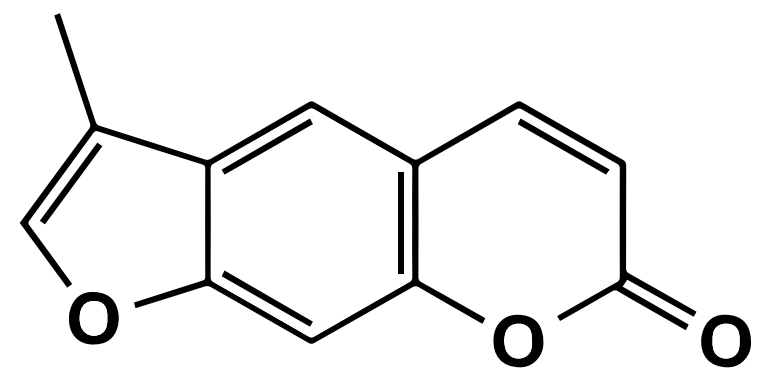

Figure 1. Structure of 3-methyl-7H-furo[3,2-g]-chromen-7-one (FCS005) 
Other reagents and drugs used in this investigation were selegiline, levodopa, carbidopa and reserpine, all supplied by Sigma-Aldrich. A MAO kit was obtained from Molecular Probes ${ }^{\mathrm{TM}}$.

\section{Animals}

We used male ICR mice six to seven weeks old (25 - $30 \mathrm{~g})$ provided by the bioterium of the Departamento de Farmacia, Facultad de Ciencias, at Universidad Nacional de Colombia. The animals were kept under standard laboratory conditions, 12-hour light-dark cycles, and at room temperature (22 $\pm 1^{\circ} \mathrm{C}$ ) with food and water available ad libitum.

The effects of FCS005 (50, 100 and $200 \mathrm{mg} / \mathrm{kg}$ ), selegiline (10 mg/ $\mathrm{kg}$ ) or the vehicle on motor activity were evaluated at 1.5 and $23.5 \mathrm{~h}$ after administration in normal mice.

In the reserpine model and I-dopa/carbidopa assays, the locomotor activity was evaluated in the open-field test. The open field was a square arena divided into 16 squares with surrounding walls to prevent escape. Animals were placed individually in the middle of the open field and the specific parameter evaluated was the number of cadres traversed during 5 minutes. The open field was cleaned with a water-alcohol (10\%) solution before placing the next animal to eliminate possible bias due to odors left by previous subjects.

\section{Evaluation of antiparkinsonian effects in the reserpine model}

We followed the experimental protocol described by Tadaiesky, et al. (24), with some modifications.

Reserpine $3 \mathrm{mg} / \mathrm{kg}$ was administrated intraperitoneally (i.p.) and 30 minutes later the mice were dosed with selegiline (10 mg/kg), FCS005 (50, 100 and $200 \mathrm{mg} / \mathrm{kg}$ ) or vehicle by oral (p.o.) administration. The vehicle was a mixture of $15 \%$ propylene glycol, $15 \%$ glycerol, and enough distilled water to make up $100 \%$. Locomotor activity was evaluated at 2 and $24 \mathrm{~h}$ after reserpine administration.

\section{Effect of L-dopa/carbidopa and MAO-B inhibitors in mice pretreated with reserpine}

We evaluated the doses of FCS005 that showed significant differences in the reserpine model. The dose of L- dopa and carbidopa that did not cause the reversal of hypokinesia was determined in a dose-response relationship (data not shown). The mice were dosed with reserpine (3 mg/kg) i.p. $30 \mathrm{~min}$ before the p.o. administration of FCS005, selegiline or the vehicle. Levodopa plus carbidopa were administrated i.p. 30 min later. Locomotor activity was evaluated at 2 and $24 \mathrm{~h}$ after the administration of reserpine.

\section{Anticataleptic effects and antioxidant activity}

Haloperidol was administered to the animals to induce rigidity and akinesia (catalepsy) $(25,26)$. Catalepsy was defined as the prolonged maintenance of both forepaws in an atypical position on a horizontal bar.

The animals received haloperidol (3 mg/kg) i.p.; FCS005 (100 mg/kg, p.o.), levodopa:carbidopa ( $400 \mathrm{mg} / \mathrm{kg}: 40 \mathrm{mg} / \mathrm{kg}$; p.o.) or vehicle (p.o) was administrated $30 \mathrm{~min}$ before. The reversal of catalepsy was evaluated for 2 min 60 min after the administration of the treatments. 
Antioxidant activity was evaluated ex vivo. Mice were administered daily for 10 days with the treatments FCS005 (50 mg/kg, p.o.), levodopa:carbidopa (400 $\mathrm{mg} / \mathrm{kg}: 40 \mathrm{mg} / \mathrm{kg}$, p.o.) or vehicle (p.o.) followed by haloperidol (1 mg/kg, i.p.) 30 min later. Then, the animals were killed by decapitation and the brains were removed, washed in $1 \% \mathrm{KCl}$, dissected on an ice-cold plate, and homogenized in $50 \mathrm{mM}$ Tris- $\mathrm{HCl}$ buffer $(\mathrm{pH}$ 7.4). Homogenates were centrifuged $(10,000$ $\mathrm{rpm}$ for $10 \mathrm{~min}$ at $4^{\circ} \mathrm{C}$ ). The final supernatant was stored at $-20^{\circ} \mathrm{C}$. The protein content of each sample was determined by the Bradford method.

The index of lipid peroxidation was evaluated following the protocol described by Hijova, et al. (27). The brain homogenate $(450 \mu \mathrm{L}), 1 \mathrm{~mL}$ trichloroacetic acid (10\%), and $50 \mu \mathrm{L}$ of $50 \mathrm{mM}$ phosphate buffer $(\mathrm{pH} 7.4)$ were centrifuged at $1850 \mathrm{xg}$ for $10 \mathrm{~min}$ at $4^{\circ} \mathrm{C}$; then, $1 \mathrm{~mL}$ of thiobarbituric acid $(0.67 \%)$ was added to $1 \mathrm{~mL}$ of the supernatant. This mixture was heated to $92^{\circ} \mathrm{C}$ for $30 \mathrm{~min}$ and then cooled in an ice bath $\left(4^{\circ} \mathrm{C}\right)$ before the absorbance was measured at $532 \mathrm{~nm}$. The results were expressed as thiobarbituric acid reactive substances (TBARS) in $\mathrm{mmol} / \mathrm{mL} / \mathrm{mg}$ of tissue protein.

Quantification of protein carbonyl groups was determined by the technique of Levine, et al. (28), following the protocol described by Baltacioglu, et al. (29). Briefly, $250 \mu \mathrm{L}$ of $10 \mathrm{mM}$ 2,4-dinitrophenylhydrazine (DNPH) or $250 \mu \mathrm{L}$ of $2 \mathrm{M} \mathrm{HCl}$ were added to the brain homogenate $(50 \mu \mathrm{L})$ for the sample or the blank, respectively. The samples were left at room temperature in the dark for $1 \mathrm{~h}$ and vigorously stirred every $15 \mathrm{~min}$. Then, $500 \mu \mathrm{L}$ of trichloroacetic acid $(20 \%)$ was added. The samples were kept in an ice bath for $15 \mathrm{~min}$ and then centrifuged at $11,000 \mathrm{rpm}$ for $5 \mathrm{~min}$. The pellet was washed three times with $1 \mathrm{~mL}$ of ethyl acetate/ethanol (1:1) solution. After each wash, the sample was centrifuged at $3,000 \mathrm{rpm}$ for $7 \mathrm{~min}$. Then, $250 \mu \mathrm{L}$ of $6 \mathrm{M}$ guanidine hydrochloride were added to the pellet to dissolve it and then it was incubated at $37^{\circ} \mathrm{C}$ for $10 \mathrm{~min}$. The absorbance was determined at $360 \mathrm{~nm}$. The content of carbonyl groups was calculated based on the molar extinction coefficient of $\operatorname{DNPH}\left(\varepsilon=22000 \mathrm{~cm}^{-1} \mathrm{M}^{-1}\right)$ and expressed as nmol/mg protein (29).

\section{Assay of human monoamine oxidase (hMAO) inhibitory activity}

The effects of FCS005 on hMAO isoform enzymatic activity were evaluated using a MAO kit (Molecular Probes ${ }^{\mathrm{TM}}$ ) using the experimental protocol previously described by Yáñez, et al. (30). Briefly, adequate amounts of recombinant hMAO-A (1.1 mg protein; specific activity: $150 \mathrm{nmol}$-tyramine oxidized to $\mathrm{p}$-hydroxyphenylacetaldehyde/min/mg protein) or hMAO-B (7.5 $\mathrm{mg}$ protein; specific activity: $22 \mathrm{nmol} p$-tyramine transformed $/ \mathrm{min} / \mathrm{mg}$ protein) were added to $0.1 \mathrm{~mL}$ of sodium phosphate buffer $(0.05 \mathrm{M}, \mathrm{pH} 7.4)$ to obtain the same reaction velocity and FCS005 in various concentrations. This mixture was incubated for $15 \mathrm{~min}$ at $37^{\circ} \mathrm{C}$ in a flat, black-bottomed 96-well microtest plate in a dark fluorimeter chamber. Then, the reaction was started by adding (final concentrations) $200 \mu \mathrm{M}$ Amplex ${ }^{\mathrm{TM}}$ Red reagent, $1 \mathrm{U} / \mathrm{mL}$ horseradish peroxidase, and $1 \mathrm{mM} p$-tyramine. The production of $\mathrm{H}_{2} \mathrm{O}_{2}$ and, consequently, of resorufin was quantified at $37^{\circ} \mathrm{C}$ in a multi-detection microplate fluorescence reader (FLX800 ${ }^{\text {TM }}$, Bio-Tek Instruments, Inc., Winooski, VT, USA) based on the fluorescence generated (emission: $590 \mathrm{~nm}$, excitation: $545 \mathrm{~nm}$ ) over a 15-min period in which the fluorescence increased linearly.

The test drugs were added to solutions containing only the Amplex ${ }^{\mathrm{TM}}$ Red reagent in a sodium phosphate buffer to determinate the capacity of FCS005 or the reference inhibitors to modify the fluorescence generated in the reaction mixture due to non-enzymatic inhibition. In the control 
experiments, the test drugs were replaced with dilutions of the vehicles. In addition, the specific fluorescence emission was calculated after subtraction of the background activity, which was determined from wells containing all components except the hMAO isoforms that were replaced by a sodium phosphate buffer solution.

\section{Statistical analysis}

Results were expressed as mean \pm standard error of the mean (SEM) and assessed by a one-way analysis of variance (ANOVA) followed by the Tukey test to determine the treatments responsible for the significant differences. When the variance was not homogeneous or the data did not show normal distribution, the Kruskal-Wallis test was applied. The data on catalepsy were processed by a two-way analysis of variance (ANOVA) with the Bonferroni post hoc test. The graphical representation and statistical analysis were performed using GraphPad Prism (v. 5.03)

\section{Ethical aspects}

All the experimental protocols were evaluated and approved by the ethics committee of the Facultad de Ciencias, Universidad Nacional de Colombia (Minutes No. 06, October 18, 2011).

\section{Results}

\section{Mice not pretreated with reserpine}

The compound FCS005 (50 mg/kg) caused a significant decrease in the locomotor activity of mice not pretreated with reserpine (figure 2) compared to the control group, both at 2 hours ( $p: 0.023$ ) and at 24 hours ( $p: 0.003$ ) post reserpine administration.
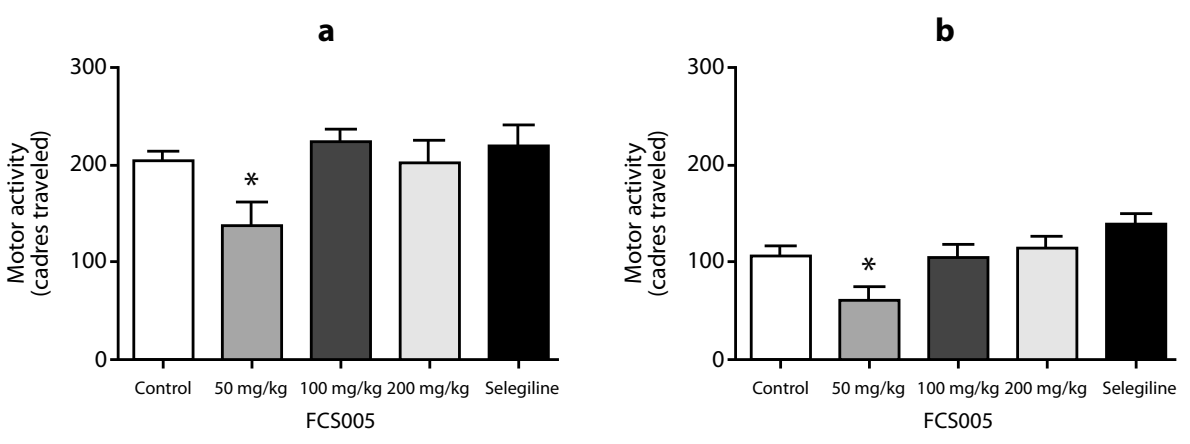

Figure 2. Mice not pretreated with reserpine. Effects on motor activity of the animals at $1.5 \mathrm{~h}$ (a) and $23.5 \mathrm{~h}$ (b) after administration of FCS005, selegiline or vehicle $(0.1 \mathrm{~mL} / 10 \mathrm{~g}$ body weight).

${ }^{*} p<0.05$ compared to the control group $(n=7-9)$

\section{Antiparkinsonian effects}

In the reserpine model, we observed that FCS005 (100 mg/kg) caused a reversal of hypokinesia produced by reserpine significantly increasing the number of cadres traversed compared to the control at $2 \mathrm{~h}$ ( $\mathrm{p}: 0.007$ ) and 24 h (p: 0.002) (figure 3). 
a

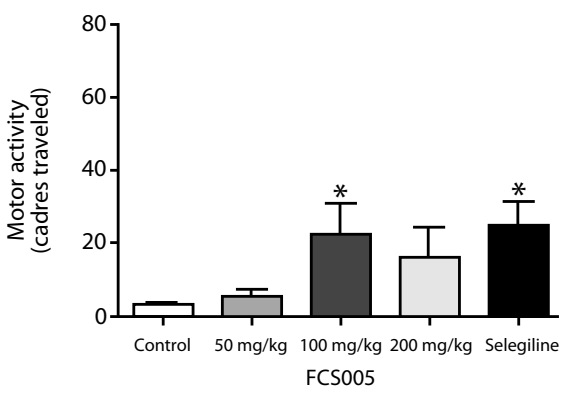

b

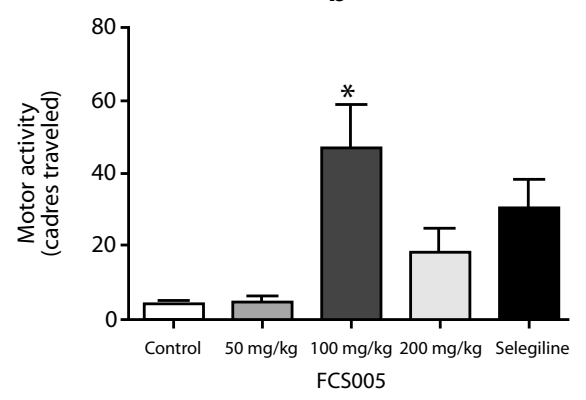

Figure 3. Reserpine model. Effects of administration of FCS005, selegiline or vehicle $(0.1 \mathrm{~mL} / 10$ $\mathrm{g}$ body weight) on motor activity of the animals at $2 \mathrm{~h}$ (a) and $24 \mathrm{~h}$ (b) after administration of reserpine.

${ }^{*} p<0.05$ compared to the control group $(n=7-9)$

\section{Effect of L-dopa/carbidopa and MAO-B inhibitors in mice pretreated with reserpine}

We evaluated the effect of concomitant administration of MAO-B inhibitors and L-dopa at low doses. We used the dose $100: 10 \mathrm{mg} / \mathrm{kg}$ of L-dopa:carbidopa given that in the dose-response relationship this dose did not lead to the reversal of hypokinesia (data not shown). We evaluated the dose of FCS005 $(100 \mathrm{mg} / \mathrm{kg})$ that showed the best response in the reserpine model. In this assay, FCS005 increased the number of cadres traversed showing a statistically significant difference compared to the control at $2 \mathrm{~h}(\mathrm{p}$ : 0.038 ) and $24 \mathrm{~h}$ (p: 0.018) (figure 4).

a

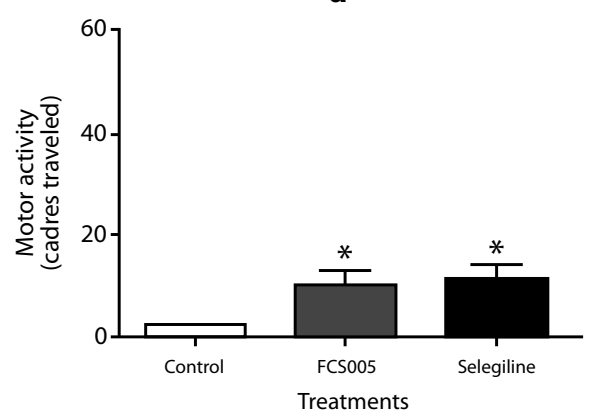

b

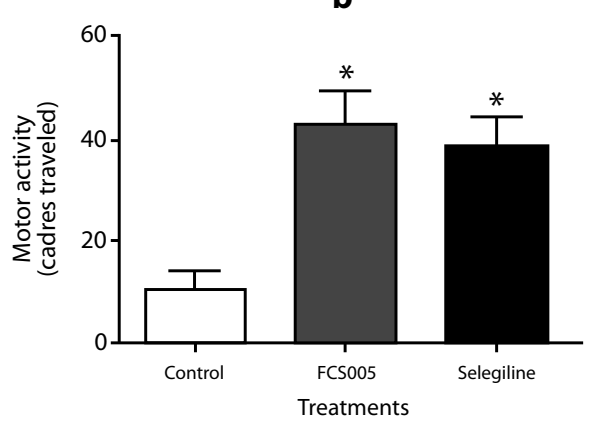

Figure 4. Effect of L-dopa/carbidopa and MAO-B inhibitors. Effects of the administration of levodopa/carbidopa (100/10 mg/kg) plus FCS005 (100 mg/kg), control $(0 \mathrm{mg} / \mathrm{kg})$ or selegiline (10 $\mathrm{mg} / \mathrm{kg}$ ) on motor activity at $2 \mathrm{~h}$ (a) and $24 \mathrm{~h}$ (b) after the administration of reserpine.

${ }^{*} p<0.05$ compared to control group $(n=7-9)$

\section{Anticataleptic effects}

The treatments showed no cataleptic effects at time zero. L-dopa/ carbidopa and FCS005 produced a significant decrease in the total catalepsy time using the horizontal bar test at $60 \mathrm{~min}$ ( $\mathrm{p}: 0.001$ ) (figure 5).

\section{Antioxidant activity}

Protein carbonyl groups and lipid peroxidation levels were lower in brain homogenates of mice treated with FCS005 and L-dopa/carbidopa compared to the control animals. The animals that did not receive haloperidol (basal state) presented lower levels than those of the control and treatments groups $(p<0.001)$ (figure 6). 


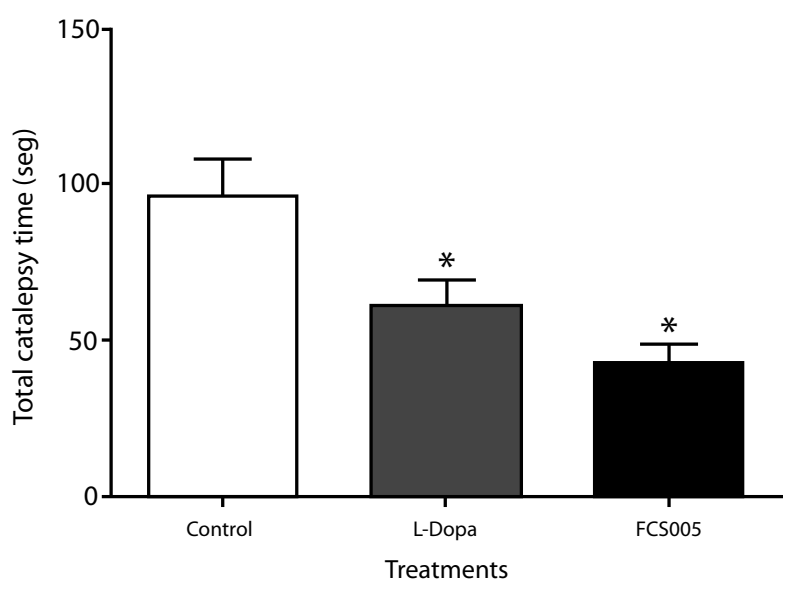

Figure 5. Anti-cataleptic effects. Catalepsy in mice was assessed using the horizontal bar test. Effects of administration of levodopa/carbidopa (400/40 mg/kg), FCS005 (100 mg/kg) or control $(0 \mathrm{mg} / \mathrm{kg})$ on catalepsy induced by haloperidol $(3 \mathrm{mg} / \mathrm{kg})$ at $60 \mathrm{~min}$

${ }^{*} p<0.05$ compared to the control group $(n=8)$

a

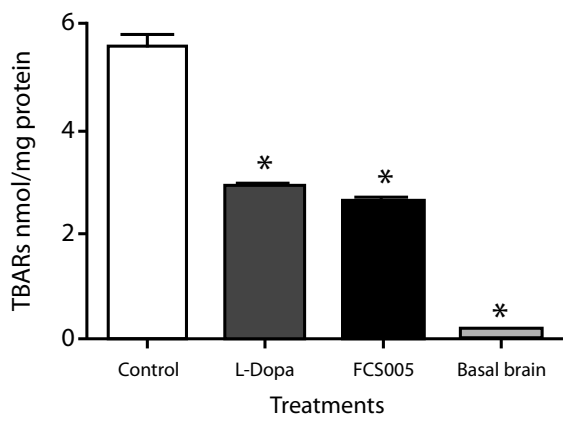

b

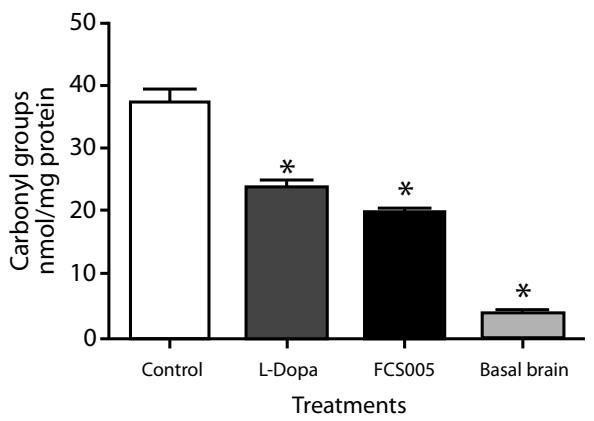

Figure 6. Antioxidant activity. Effect of FCS005 (50 mg/kg), control $(0 \mathrm{mg} / \mathrm{kg})$ or levodopa/ carbidopa (400/40 mg/kg) on (a) lipid peroxidation and (b) the oxidation of carbonyl groups of proteins in brain homogenates of mice treated with haloperidol $(1 \mathrm{mg} / \mathrm{kg})$ for 10 days ${ }^{*} p<0.05$ compared to the control group $(n=8)$

\section{In vitro inhibition of the $A$ and $B$ isoforms of MAO}

FCS005 presented selective inhibitory activity towards MAO-B. This coumarin analogue did not inhibit MAO-A isoform activity at the highest concentration tested $(100 \mu \mathrm{M})$. The reference inhibitors and FCS005 did not interfere with the measurements because these drugs did not react directly with the Amplex ${ }^{\mathrm{TM}}$ Red reagent. The corresponding $\mathrm{IC}_{50}$ values and the selectivity index $\left[\mathrm{IC}_{50}(\mathrm{hMAO}-\mathrm{A})\right] /\left[\mathrm{IC}_{50}\right.$ (hMAO-B)] are shown in table 1.

Table 1. In vitro inhibitory activities of reference compounds and FCS005 towards hMAO-A and hMAO-B isoforms ${ }^{a}$

\begin{tabular}{lrrr}
\hline Compounds & \multicolumn{1}{c}{ hMAO-A $\left(\mathbf{I C}_{50}\right)$} & \multicolumn{1}{c}{ hMAO-B $\left(\mathbf{I C}_{50}\right)$} & Selectivity index $^{\mathbf{b}}$ \\
\hline FCS005 & $*$ & $41.63 \pm 2.79 \mu \mathrm{M}$ & $>2.4^{\mathrm{c}}$ \\
Clorgiline & $4.46 \pm 0.32 \mathrm{nM}$ & $61.35 \pm 1.13 \mu \mathrm{M}$ & 0.000073 \\
Selegiline & $67.25 \pm 1.02 \mu \mathrm{M}$ & $19.60 \pm 0.86 \mathrm{nM}$ & 3.431 \\
Iproniazide & $6.56 \pm 0.76 \mu \mathrm{M}$ & $7.54 \pm 0.36 \mu \mathrm{M}$ & 0.87 \\
\hline
\end{tabular}

${ }^{a}$ Each IC50 value is the mean \pm S.E.M. from five experiments $(n=5)$.

${ }^{\mathrm{b}}$ hMAO-B selectivity ratios [IC50 (hMAO-A)]/[IC50 (hMAO-B)] for inhibitory effects of FCS005 compound and reference inhibitors

${ }^{c}$ Values obtained under the assumption that the corresponding IC50 against hMAO-A is the highest concentration tested $(100 \mu \mathrm{M})$

* Inactive at $100 \mu \mathrm{M}$ (highest concentration tested) 


\section{Discussion}

The antiparkinsonian activity of FCS005 was evaluated in mice using the reserpine model. The effect of reserpine on spontaneous locomotor activity is frequently used as a model of motor disturbances in Parkinson's disease $(24,31,32,33)$. Some drugs currently on the market were tested in this model suggesting it has predictive validity $(24,33)$.

Hypokinesia occurs in mice because reserpine blocks the vesicular monoamine transporter and produces a profound and lasting decrease in catecholamines, a situation that results in the depletion of DA in all dopaminergic nerve terminals including the nigrostriatal pathway $(14,18)$. FCS005 $(100 \mathrm{mg} / \mathrm{kg})$ caused the significant reversal of hypokinesia in the reserpine and levodopa models. This could be explained by the fact that the synthetic coumarin FCS005 showed selective inhibitory activity against hMAO-B in vitro. MAO inhibitors reduce the enzymatic degradation of dopamine by MAO, thus leading to an increase in monoamines and striatal dopaminergic activity and improving motor symptoms in Parkinson's disease $(34,35)$. Dopamine acts on postsynaptic $D_{1}$ and $D_{2}$ receptors to control movement (36). The selective inhibitory activity on MAO type B prolongs the activity of both endogenously and exogenously derived dopamine, which represents an option either as monotherapy in early Parkinson's disease or as adjuvant therapy in patients treated with levodopa when they experience motor complications (35). Selegiline and rasagiline, selective inhibitors of MAO-B, are used in clinical practice to improve the response to L-dopa at later stages of the disease (7).

FCS005 at a dose of $50 \mathrm{mg} / \mathrm{kg}$ led to a significant decrease in motor activity in mice not treated with reserpine. However, this did not affect the evaluation in the models of reserpine and levodopa where the reversal of hypokinesia was evaluated. On the other hand, the decrease in motor activity at $24 \mathrm{~h}$ with all treatments could be attributed to habituation that occurs due to repeated exposure to the open field $(37,38)$.

The coumarin analogue FCS005 showed anti-cataleptic effects in the haloperidol model. The animals presented catalepsy and muscular rigidity because haloperidol blocks nigrostriatal dopamine transmission $(39,40)$. These symptoms may be analogous to the inability of Parkinson's disease patients to initiate movements (40). FSC005 did not show any cataleptic effects.

Some studies have shown that chronic administration of haloperidol induces increased levels of lipid peroxidation and decreased levels of antioxidant enzymes and reduced glutathione $(41,42)$. Besides, the results of Martins, et al. (43) showed that TBARS increased in the striatum after the administration of haloperidol in repeated doses. In this study, an increase in the TBARS concentration was also observed, possibly because dopamine receptors were blocked by haloperidol leading to an increase in dopamine and, therefore, to the production of hydrogen peroxide and other toxic metabolites of dopamine $(44,45)$. Hydrogen peroxide in the presence of $\mathrm{Fe}^{2+}$ and $\mathrm{Cu}^{2+}$ produces hydroxyl radical capable of oxidizing almost any cell structure, which leads to neurodegeneration and contributes to the development of pathologies (46). Antioxidants, free radical scavengers, and similar drugs have been potentially used in therapeutic development to prevent Parkinson's disease. The results of some authors suggest that coumarins and flavonoids can directly capture the reactive oxygen species (47). FCS005 had a significant protective effect against oxidative stress, 
probably because MAO-B inhibitors can reduce oxidative stress by reducing $\mathrm{H} 2 \mathrm{O} 2$ production, thus acting as neuroprotective agents (34).

FCS005 (3-methyl-7H-furo[3,2-g]-chromen-7-one) is a furocoumarin with a structure similar to that of psoralen, which is isolated from the plant Psoralea corylifolia L. and is used traditionally to treat ageing. Psoralen was demonstrated to exhibit in vitro inhibitory actions on MAO activities in rat brain mitochondria, preferentially inhibiting MAO-A activity over MAO-B activity (48) while FCS005 exhibited selective MAO-B inhibitory activity, which could be attributed to the substitution at position 3; this is the only difference between the two structures.

In conclusion, the coumarin analogue FCS005 synthesized in this research led to the reversal of hypokinesia in the reserpine and levodopa models of Parkinson's disease and demonstrated anticataleptic effects. Besides, it showed selective inhibitory activity towards MAO-B, as well as antioxidant activity. These results attribute interesting properties to FCS005 supporting further investigations on its potential as an antiparkinsonian agent including the use of models useful to asses not only the control of symptoms but, especially, neuroprotection.

\section{References}

1. Elbaz A, Carcaillon L, Kab S, Moisan F. Epidemiology of Parkinson's disease. Rev Neurol (Paris). 2016;172:14-26. https://doi.org/10.1016/j.neurol.2015.09.012

2. Dorsey ER, Constantinescu R, Thompson JP, Biglan KM, Holloway RG, Kieburtz K, et al. Projected number of people with Parkinson disease in the most populous nations, 2005 through 2030. Neurology. 2007;68:384-6. https://doi.org/10.1212/01.wnl.0000247740.47667.03

3. Connolly BS, Lang AE. Pharmacological treatment of Parkinson disease: A review. JAMA. 2014; 311:1670-83. https://doi.org/10.1001/jama.2014.3654

4. Alexi T, Borlongan C, Faull R, Williams C, Clark R, Gluckman P, et al. Neuroprotective strategies for basal ganglia degeneration: Parkinson's and Huntington's diseases. Prog Neurobiol. 2000;60:409-70. https://doi.org/10.1016/S0301-0082(99)00032-5

5. Emborg M. Evaluation of animal models of Parkinson's disease for neuroprotective strategies. J Neurosci Methods. 2004;139:121-43. https://doi.org/10.1016/j.jneumeth.2004.08.004

6. Gershanik OS. Improving L-dopa therapy: The development of enzyme inhibitors. Mov Disord. 2015;30:103-13. https://doi.org/10.1002/mds.26050

7. Finberg J. Update on the pharmacology of selective inhibitors of MAO-A and MAO-B; focus on modulation of CNS monoamine neurotransmitter release. Pharmacol Ther. 2014;143:133-52. https://doi.org/10.1016/j.pharmthera.2014.02.010

8. Ariza S, Rueda D, Rincón J, Linares E, Guerrero M. Efectos farmacológicos sobre el sistema nervioso central inducidos por cumarina aislada de Hygrophila tyttha Leonard. Vitae. 2007;14:51-8.

9. Vergel N, López J, Orallo F, Viña D, Buitrago D, Olmo E, et al. Antidepressant-like profile and MAO-A inhibitory activity of 4-propyl-2H-benzo[h]- chromen-2-one. Life Sci. 2010;86:819-24. https://doi.org/10.1016/j.Ifs.2010.04.001

10. Matos M, Viña D, Picciau C, Orallo F, Santana L, Uriarte E. Synthesis and evaluation of 6-methyl-3-phenylcoumarins as potent and selective MAO-B inhibitors. Bioorg Med Chem Lett. 2009;19:5053-5. https://doi.org/10.1016/j.bmcl.2009.07.039

11. Matos M, Viña D, Quezada E, Picciau C, Delogu G, Orallo F, et al. A new series of 3-phenylcoumarins as potent and selective MAO-B inhibitors. Bioorg Med Chem Lett. 2009;19:3268-70. https://doi.org/10.1016/j.bmcl.2009.04.085

12. Matos M, Viña D, Janeiro $P$, Borges $F$, Santana L, Uriarte $E$. New halogenated 3-phenylcoumarins as potent and selective MAO-B inhibitors. Bioorg Med Chem Lett. 2010;20:5157-60. https://doi.org/10.1016/j.bmcl.2010.07.013

13. Matos M, Viña D, Vázquez-Rodríguez S, Uriarte E, Santana L. Focusing on new monoamine oxidase inhibitors: Differently substituted coumarins as an interesting scaffold. Curr Top Med Chem. 2012;12:2210-39. https://doi.org/10.2174/1568026611212200008 
14. Matos M, Vilar S, González-Franco R, Uriarte E, Santana L, Friedman C, et al. Novel (coumarin-3-yl) carbamates as selective MAO-B inhibitors: Synthesis, in vitro and in vivo assays, theoretical evaluation of ADME properties and docking study. Eur J Med Chem. 2013;63:151-61. https://doi.org/10.1016/j.ejmech.2013.02.009

15. Pisani L, Farina R, Nicolotti $O$, Gadaleta $D$, Soto-Otero $R$, Catto $M$, et al. In silico design of novel $2 \mathrm{H}$-chromen-2-one derivatives as potent and selective MAO-B inhibitors. Eur J Med Chem. 2015;89:98-105. https://doi.org/10.1016/j.ejmech.2014.10.029

16. Epifano F, Molinaro G, Genovese S, Ngomba R, Nicoletti F, Curini M. Neuroprotective effect of prenyloxycoumarins from edible vegetables. Neurosci Lett. 2008;443:57-60. https://doi.org/10.1016/j.neulet.2008.07.062

17. Liu WB, Zhou J, Qu Y, Li X, Lu CT, Xie KL, et al. Neuroprotective effect of osthole on MPP+-induced cytotoxicity in PC12 cells via inhibition of mitochondrial dysfunction and ROS production. Neurochem Int. 2010;57:203-15. https://doi.org/10.1016/j.neuint.2010.05.011

18. Philippens I. Non-human primate models for Parkinson's disease. Drug Discov Today Dis Models. 2008;5:105-11. https://doi.org/10.1016/j.ddmod.2008.06.004

19. Matos M, Rodríguez F, Borges F, Santana L, Uriarte E, Estrada M, et al. 3-Amidocoumarins as potential multifunctional agents against neurodegenerative diseases. ChemMedChem. 2015;10:2071-9. https://doi.org/10.1002/cmdc.201500408

20. Aguirre P, García O, Tapia V, Muñoz Y, Cassels BK, Núñez MT. Neuroprotective effect of a new 7,8-dihydroxycoumarin-based Fe2+/Cu2+ chelator in cell and animal models of Parkinson's disease. ACS Chem Neurosci. 2017;8:178-85. https://doi.org/10.1021/acschemneuro.6b00309

21. Reglodi D, Renaud J, Tamas A, Tizabi Y, Socías SB, Del-Bel E, et al. Novel tactics for neuroprotection in Parkinson's disease: Role of antibiotics, polyphenols and neuropeptides. Prog Neurobiol. 2017;155:120-48. https://doi.org/10.1016/j.pneurobio.2015.10.004

22. Garazd M, Garazd Y, Ogorodniichuk A, Khilya V. Modified coumarins. Synthesis of substituted 5-(4-methoxyphenyl)-7H-furo [3,2-g] chromen-7-ones. Chem Nat Compd. 2002;38:539-48. https://doi.org/10.1023/A:1022626402415

23. National Center for Biotechnology Information. PubChem Open Chemistry Database Compound Summary for CID 608273. Accessed on: January 20, 2018. Available at: https:// pubchem.ncbi.nlm.nih.gov/compound/608273

24. Tadaiesky M, Andreatini R, Vital M. Different effects of 7-nitroindazole in reserpine-induced hypolocomotion in two strains of mice. Eur J Pharmacol. 2006;535:199-207. https://doi.org/10.1016/j.ejphar.2006.02.004

25. Schmidt W, Mayerhofer A, Meyer A, Kovar K. Ecstasy counteracts catalepsy in rats, an antiparkinsonian effect? Neurosci Lett. 2002;330:251-4.

26. Wei L, Chen L. Effects of $5-\mathrm{HT}$ in globus pallidus on haloperidol-induced catalepsy in rats. Neurosci Lett. 2009;454:49-52. https://doi.org/10.1016/j.neulet.2009.02.053

27. Hijova E, Nistiar F, Sipulova A. Changes in ascorbic acid and malondialdehyde in rats after exposure to mercury. Bratis Lek Listy. 2005;106:248-51.

28. Levine R, Garland D, Oliver C, Amici A, Climent I, Lenz A, et al. Determination of carbonyl content in oxidatively modified proteins. Methods Enzymol. 1990;186:464-78. https://doi.org/10.1016/0076-6879(90)86141-H

29. Baltacioglu E, Akalin FA, Alver A, Deger O, Karabulut E. Protein carbonyl levels in serum and gingival crevicular fluid in patients with chronic periodontitis. Arch Oral Biol. 2008;53:716-22. https://doi.org/10.1016/j.archoralbio.2008.02.002

30. Yáñez M, Fraiz N, Cano E, Orallo F. Inhibitory effects of cis- and trans-resveratrol on noradrenaline and 5-hydroxytryptamine uptake and on monoamine oxidase activity. Biochem Biophys Res Commun. 2006;344:688-95. https://doi.org/10.1016/j.bbrc.2006.03.190

31. Colpaert F. Pharmacological characteristics of tremor, rigidity and hypokinesia induced by reserpine in rats. Neuropharmacology. 1987;26:1431-40.

32. Kaur S, Starr M. Antiparkinsonian action of dextramethorphan in the reserpine-treated mouse. Eur J Pharmacol. 1995;280:159-66.

33. Menzaghi F, Whelan K, Risbrough V, Rao T, Lloyd G. Interactions between a novel cholinergic ion channel agonist, SIB-1765F and L-DOPA in the reserpine model of Parkinson's disease in rats. J. Pharmacol Exp Ther. 1997;280:393-401. 
34. Foley P, Gerlach M, Youdim M, Riederer P. MAO-B inhibitors: Multiple roles in the therapy of neurodegenerative disorders? Parkinsonism Relat Disord. 2000;6;25-47. https://doi.org/10.1016/S1353-8020(99)00043-7

35. Fernández $\mathrm{H}$, Chen J. Monoamine oxidase-B inhibition in the treatment of Parkinson's disease. Pharmacotherapy. 2007;27:174S-85S. https://doi.org/10.1592/phco.27.12part2.174S

36. Fisher A, Biggs C, Eradiri O, Starr M. Dual effects of L-3,4-dihydroxyphenylalanine on aromatic L-amino acid decarboxylase, dopamine release and motor stimulation in the reserpine-treated rat: Evidence that behavior is dopamine independent. Neuroscience. 2000;95:97-111. https://doi.org/10.1016/S0306-4522(99)00406-6

37. Haleem DJ, Inam QU, Haleem MA. Effects of clinically relevant doses of methyphenidate on spatial memory, behavioral sensitization and open field habituation: A time related study. Behav Brain Res. 2015;281:208-14. https://doi.org/10.1016/j.bbr.2014.12.031

38. Deacon RM, Koros E, Bornemann KD, Rawlins JN. Aged Tg2576 mice are impaired on social memory and open field habituation tests. Behav Brain Res. 2009;197:466-8. https://doi.org/10.1016/j.bbr.2008.09.042

39. Wang X, Han C, Xu Y, Wu K, Chen S, Hu M, et al. Synthesis and evaluation of phenylxanthine derivatives as potential dual A2AR antagonists/MAO-B inhibitors for Parkinson's disease. Molecules. 2017;22:1-13. https://doi.org/10.3390/molecules22061010

40. Duty S, Jenner P. Animal models of Parkinson's disease: A source of novel treatments and clues to the cause of the disease. Br J Pharmacol. 2011;164:1357-91. https://doi.org/10.1111/j.1476-5381.2011.01426.x

41. Bishnoi M, Chopra K, Kulkarni S. Involvement of adenosinergic receptor system in an animal model of tardive dyskinesia and associated behavioural, biochemical and neurochemical changes. Eur J Pharmacol. 2006;552:55-66. https://doi.org/10.1016/j.ejphar.2006.09.010

42. Bishnoi M, Chopra K, Kulkarni S. Possible anti-oxidant and neuroprotective mechanisms of zolpidem in attenuating typical anti-psychotic-induced orofacial dyskinesia -A biochemical and neurochemical study. Prog Neuropsychopharmacol Biol Psychiatry. 2007;31:1130-8. https://doi.org/10.1016/j.pnpbp.2007.04.007

43. Martins M, Petronilho F, Gomes K, Dai-Pizzol F, Streck E, Quevedo J. Antipsychotic induced oxidative stress in rat brain. Neurotox Res. 2008;13:63-9. https://doi.org/10.1007/BF03033368

44. Naidu P, Singh A, Kulkarni S. Quercetin, a bioflavonoid attenuated haloperidol induced orofacial dyskinesia. Neuropharmacology. 2003;44:1100-6. https://doi.org/10.1016/S0028-3908(03)00101-1

45. Singh A, Naidu P, Kulkarni S. Possible antioxidant and neuroprotective mechanisms of FK506 in attenuating haloperidol-induced orofacial dyskinesia. Eur J Pharmacol. 2003;477:87-94. https://doi.org/10.1016/S0014-2999(03)02124-1

46. Pavshintsev VV, Podshivalova LS, Frolova OY, Belopolskaya OA, Averina OA, Kushnir EA, et al. Effects of mitochondrial antioxidant SkQ1 on biochemical and behavioural parameters in a Parkinsonism model in mice. Biochemistry (Mosc). 2003;82:1513-20. https://doi.org/10.1134/S0006297917120100

47. Molina-Jiménez M F, Sánchez-Reus M I, Benedi J. Effect of fraxetin and myricetin on rotenone-induced cytotoxicity in $\mathrm{SH}-\mathrm{SY} 5 Y$ cells: Comparison with $\mathrm{N}$-acetylcysteine. Eur $\mathrm{J}$ Pharmacol. 2003;472:81-7. https://doi.org/10.1016/S0014-2999(03)01902-2

48. Kong LD, Tan RX, Woo AY, Cheng $\mathrm{CH}$. Inhibition of rat brain monoamine oxidase activities by psoralen and isopsoralen: Implications for the treatment of affective disorders. Pharmacol Toxicol. 2001;88:75-80. 